\title{
War, Art and the New Experience of the Crowd
}

\author{
Ekaterina Bobrinskaya \\ Department of Fine arts and architecture \\ State Institute for Art Studies \\ Moscow, Russia \\ E-mail: ekaterina173@gmail.com
}

\begin{abstract}
The paper deals with a new turn occurred in crowd mythology on the eve of the First World War. The crowd now becomes not merely an object under observation. The crowd of society, or "diffused crowd", transforms into material that is organised and formalised. The new image of the organised and regulated crowd gradually squeezes out the earlier images of spontaneous, criminal and uncontrollable crowds. Instead of crowds shown through the metaphors of the stormy fire or water elements, as scary monsters or an eerie insect, there appears a new range of associations, including the crowd as a machine, a controlled mechanism.
\end{abstract}

Keywords-crowd mythology; the crowd as a machine; art; collective bodies; rhythm; ornament

\section{INTRODUCTION}

In his essay "The Mass Ornament" written in the late 1920s Siegfried Kracauer gave a brilliant description of the new image of the masses born of the spirit of modernity. Analysing "the patterns seen in the stadiums and cabarets", he pointed out their geometrical precision, rationality and at the same time mythical nature, "the predominance of abstractness' and anonymity, their mute nature and impenetrability. For him "the mass ornament is the aesthetic reflex of the rationality to which the prevailing economic system aspires" [1], that is, the capitalist production process. I will dwell on the preceding period in the history of such ornaments. They take shape at the crossing points of different phenomena in culture and find reflection not only in "the patterns of stadiums and cabarets". In the early 20th century peculiar utopias of construction were formed with the help of the rhythms of new harmonious man and society. It was in those utopian models that the mass ornaments originated.

The First World War certainly helped liven up all sorts of collectivist myths. Of course, they did not come to life exclusively under the impact of the war. However, it was the military experience and specific army (or war) aesthetics that became an important component of the new mass image. During the war, Russian society not only experienced military victories, dramas and the shock of disillusionment with the ideas of progress. It expected its entire past life transform with the great war, ushering in a new reality. S. Bulgakov wrote in 1915: "The course of history is accelerating convulsively, and if there is any end at all, it is clear that the world is rushing towards this mysterious, horrible and radiant end of its current eon. (...) Those who have ears to hear have long anticipated, and now even more so than earlier, the coming of the Future as an entirely new era in the history of humanity"[2]. Those sentiments not only bred apocalyptic expectations, but also invigorated the ideas of the rational building of a "new sky and new earth". The mass of the people often serves as the instrument and at the same time material for building the transformed future.

\section{A NEW TURN OCCURRED IN CROWD MYTHOLOGY}

On the eve of the First World War a new turn occurred in crowd mythology. The crowd was increasingly viewed not as a spontaneous force, but as a model of contemporary society. At the very beginning of the century, G. Tarde formulated the concept of a "diffused crowd", or public crowd, which is subject to the same laws of crowd psychology as the common crowd. The "diffused crowd" is in fact the equivalent of society. The laws operating in the crowd, as well as relations and dependencies arising in it are also operative in society as such. The crowd is a society in the state of chaos and barbarity. E. Durkheim expounded a similar view of the crowd in his writings. According to him, "society is but a stable and organised crowd"[3]. Recognising the important role played by the irrational forces in social life, Durkheim stressed the necessity for their rational organisation and spoke of the need for control and discipline (as distinct from Le Bon's manipulative strategies) in interacting with crowds. "A mob or a crowd is a society, but one that is inchoate, unstable, without regularly organized discipline. Because it is a society the strong emotional forces generated in the crowd are especially intense. Therefore, they move quickly to excesses. A forceful and complex system of regulation is required to enclose them within limits, to prevent them from bursting all bounds" [4]. In the postwar period they speak ever more frequently about society as a more stable association of people which is not so transient as the usual crowds but which, nevertheless, is subject to laws similar to those that govern the crowds.

The First World War not only triggered the invasion of social life by spontaneous forces, but also promoted the development of instruments influencing the crowd of society. During the war propaganda becomes an extremely active force. All sorts of mass media bring increasingly bigger masses of people into their orbit and their role in social life becomes ever more notable. In his book Dusha armii (The Soul of the Army), written already after the calamities of the First World War and the revolution, General P. Krasnov 
observes: "Modern culture makes it possible to influence the feelings of the people in countless ways and means. Messages, briefings, political leaflets, newspapers, books, meetings, debates, the theatre, the cinema and the wireless telegraph have all broadened the concept of the crowd and made human society to a certain extent similar to the crowd"[5].

The crowd now becomes not merely an object under observation. The crowd of society, or "diffused crowd", transforms into material that is organised and formalised. The new image of the organised and regulated crowd gradually squeezes out the earlier images of spontaneous, criminal and uncontrollable crowds. Instead of crowds shown through the metaphors of the stormy fire or water elements, as scary monsters or an eerie insect, there appears a new range of associations, including the crowd as a machine, a controlled mechanism. Incidentally, that machine is full of energy and vital power. The new image of a "living machine" rests both on the archaic means of creating collective bodies and on purely modern practices. Let me briefly dwell on some of them.

The ideas of shaping the mass of the people aesthetically, literally giving them shape, are largely traced to army experience. The army is a major collective force operating in society. This collective does not come into being spontaneously or by chance. It is organised and built deliberately. The army develops its own methods of aestheticising and constructing a single organism out of many people. Military parades are one of the ways of demonstrating the ideal collective organism. The utopian construction of the ideal collective body, a prototype of an ideal socium, has always been characteristic of armies of modern history. Military parades can be viewed as the most graphic manifestation of such construction of the ideal collective organism. Juri Lotman pointed out that in the 19th century "the parade became an aestheticised model of the ideal of not only military but also universal government organisation". 1 Many 19th-century pictures of military parades show the multitude of people as regularised and inscribed into regular geometrical shapes, rhythmically organised and conforming to the ideal order (G. Chernetsov, Parade Celebrating the End of Military Action in the Kingdom of Poland in St. Petersburg on 6 October 1831, the 1830s, State Russian Museum; A. Ladurner, The Consecration of the Alexander Column in St. Petersburg on 30 August 1834, the 1830s, State Russian Museum). Automatism and uniform movements, or to quote G. Tarde, "the law of imitation", are characteristic of both marching troops and crowds. A special psychological mechanism is also operative in the crowd making people head in the same direction and perform similar movements.

The military paid attention to the similar psychological mechanisms governing the crowd and the army. Studies on military psychology based on the ideas of "crowd

\footnotetext{
${ }^{1}$ Juri Lotman, Izbrannye stat'yi (Selected Articles). Vol. 1. Articles on Semiotics. "Kultura i programmy povedeniya" (Culture and Behavior Programmes).

http://www.fedy-diary.ru/html/102010/16102010-01c.html
}

psychology" appeared in Russia in the 1910s. The more significant of them were the books of General N. Golovin Issledovanie boia (The Study of Battle, 1907) and of the army prosecutor A. Rezanov Armia i tolpa (The Army and the Crowd, 1910), who viewed the army as a specific type of crowd. "Large modern armies in the field, despite the actual distance separating their positions, are sheer psychological crowds," [6]. Rezanov wrote. Military formation and marching were the key instruments of controlling the crowd of an army. "Formation is a stable deliberate organisation that enslaves the personality to the greatest degree. With the help of formation we deliberately combine the crowd's susceptibility, thus attaining, first, its easy control, second, tenacity and, third, the steady intensity of inner energy," [7] Rezanov went on to say. P. Krasnov argued in the same vein: "The formation is a crowd to be made a psychological crowd obedient to the will of the superior. Close formation, marching in step to drum beat or music, the orderly movement of a column with songs and the ceremonial march to the regiment band are all means of teaching people to forget their egos and embrace the collective regiment soul." [8].

It is important to stress that the military saw outward organisation not only as a means of physically controlling the crowd, but also as an instrument of influencing the psyche and the mind. "One outward organisation of the crowd or another definitely influences its spiritual qualities," [9] Rezanov wrote. Nor did the military ignore crowd irrationality. Referring to G. Tarde, Rezanov stressed that "the problem of collective psychology, and army psychology as its constituent, lies essentially in our subconscious life"; "a military command or order are suggestions" [10]. The somnambulic nature of crowds under the impact of a suggestion was the key idea of crowd psychology. The qualities of a somnambulist are also attributed to the crowd of society. "Tarde, summarising his own ideas on the subject, declared that: The social like the hypnotic state is only a form of dream, a dream of command and a dream of action. Both the somnambulist and the social man are possessed by the illusion that their ideas, all of which have been suggested to them, are spontaneous" [11].

Wartime willy-nilly promoted the spread of militarised aesthetics and the army ways of organising and aestheticising the mass of the people. A peculiar hybrid of the army methods of strict outward organisation of the masses and the somnambulist state typical of the crowd became one of the more topical models for collectivist utopias. I will briefly dwell on practices of building and aestheticising collective bodies directly or indirectly associated with army aesthetics that were common in the $1910 \mathrm{~s}$.

The ideal collective bodies were built not only at parades, but also at sports clubs and stadiums. In The History of the Body G. Vigarello and R. Holt point to the growing importance of diverse sports and gymnastic movements in social life at the turn of the 20th century and also to their militarised nature: "thanks to collective physical exercises there appeared a means of mobilising the population and influencing the mass of the people"; "A meeting place and a symbol of energy, gymnastic society has become firmly 
established as a new form of collective mobilisation"[12]. The standardisation of individual bodies in gymnastic clubs combined with the mythologisation of progress that was capable of not only inventing new and ever more perfect mechanism, but also of inspiring efforts to improve and develop individual bodies.

Public performances of gymnasts (like parades) become a common practice of building ideal collective bodies. Sokol gymnastics had a special role to play in aestheticising those collective bodies. Founded in Austro-Hungary in the mid19th century, it enjoyed tremendous popularity at the turn of the 20th century and emerged as a movement with a ramified network of international branches. In the early 20th century Russia had numerous Sokol gymnastics clubs. The Sokol movement represented not only gymnastics per se, but also a certain ideology - Pan-Slavism, the ideas of the unification and revival of the Slavic nations and of creating a uniform national organism through physical fitness. A focus on the aesthetic aspect of all exercises was an important feature of Sokol gymnastics that was characterised by strict rhythm, symmetrical compositions and neat movements. Special attention was paid to collective training. Such exercises involved thousands of people and produced an overwhelming impression on the public at Sokol slets (gymnastic festivals). V. Bekhterev, who attended one of the Sokol slets in Prague, described his impressions as follows: "Sokol exercises were distinguished by magnificence beyond description. Those who did not see a mass of twelve thousand young people on a vast field two or three times the size of our Field of Mars, having marched ceremoniously and broken into separate columns, on the wave of a hand take a pose with arms outstretched and touching one another, all the while spread around the vast space of the field, and then, after that picture of fantastic beauty, start making intricately beautiful formations to music, are unable to imagine the impression this live moving mass produces and how it captivates the viewer"[13].

Dalcroze eurhythmics, too, play a serious part in developing the instruments of aestheticising collective bodies. Here are few characteristics of eurhythmics that I find essential. Dalcroze saw military marching and the specific rhythm of step as the primary element of his rhythmic system (initially he called his gymnastics precisely "faire les cent pas ", or pace around). "Of all movements marching is most likely to become mechanical. Therefore the march is, so to speak, the alpha and omega of our method,"[14] Dalcroze wrote. Another important characteristic of eurhythmics is its emphasis on collective experience. The staging of mass festivities in Switzerland and mass scenes in Hellerau performances formed the pride of the Dalcroze movement. Dalcroze introduced the concept "foule-artiste» (crowd actor) and developed special methods of creating a scenic crowd effect. He spoke primarily of attaining "a unity of collective gesture" and the unconditional need to renounce individual expressiveness: "changes of gesture and attitudes, while walking or running, of a collection of individuals will produce a harmonious effect on the spectator only by a subordination of each individual gesture in favour of the whole. The crowd must be considered by the producer as an entity, a single individual, with many limbs"; “...each individual, whether in the chorus or outside it, must sacrifice his particular idiosyncrasies of expression in the interests of the general impression"[15].

Rhythm is what army and gymnastics practices of producing collective bodies have in common. In the early 20th century rhythm was not merely an aesthetical category, but a truly myth-making force. It was regarded as an analogue of vital power that pervades everything and governs cosmos and socium, the human body and mind. "Rhythmicity is the primordial quality of man as a particle of the universe. Nobody and nothing exists without rhythm, because life is nothing but movement in rhythm," wrote one of the Russian followers of Dalcroze [16]. The elements of life and of rhythm are extremely close, nearly identical. They are the sources that are superior to the individual, who against his will finds himself at their mercy. Rhythmic force is also reminiscent of special collective energy that operates in the crowds, making a single entity of a multitude of people. Finally, still another important quality of rhythm is its link with the sense of pleasure. In his once popular book Arbeit und Rhythmus (Labour and Rhythm, 1896) the famous German economist K.Bucher points out: "Rhythm evokes a pleasant feeling and for this reason serves not only to ease work, but also as a source of aesthetical pleasure and that element of art, a sense of which is innate in all people at whatever rung of education they are"[17]. In other words, rhythm is an element most accessible to mass aesthetic feeling. Rhythm is an instrument of harmonising not only the human mind and physical body, but also society. It promotes the development of collective feeling. At the same time it is a vital subversive force that undermines rationality and the stable contours of the individual, a force capable of enchanting and subjugating.

In the late 1910s, the rhythm mythology saw the focus shift gradually from the aesthetic to the utilitarian, conventionally speaking, from dance rhythms to those of labour, from ecstatic rhythms to mechanical, from natural rhythm to that of marching. In the new images of the wartime and postwar masses the army model of aestheticising collective bodies combined with that of labour, the spontaneous vital force with the principle of organisation, the body with the mechanism, with rhythm cementing them all and adding a sense of pleasure. The ideal collective bodies, involved in labour, organised, disciplined and imbued with the common pleasure of rhythm retain the archaic core behind their rational contemporary façade. Describing the aborigines dance Hoku-loa, Marcel Mauss gives an impressive picture of such an archaic collective body. His description conforms to the nature of the new rhythmically organized masses. "The whole social body is animated by the same movement. There are no longer any individuals, for they have all become, as it were, the parts of a machine, or, to use an even better image, the spokes of a wheel... This rhythmical, uniform and continuous movement is the direct expression of mental state in which each individual consciousness is possessed by a single feeling, a single idea, the hallucinating idea of the common aim. Each body has the same swing, each face the same mask, each 
voice utters the same cry. $\langle\ldots>$ All are at one, caught up in the dance and enraptured by their agitation, and become a single body and a single soul. It is only at that point the social body truly becomes real, for it is then that its cells, the individuals composing it, are as close to each other as the cells in an individual organism"[18].

\section{RHYTHMICAL UTOPIAS AND PRACTICES OF PRODUCING IDEAL COLLECTIVE BODIES IN ART}

Rhythmical utopias and practices of producing ideal collective bodies found both direct and indirect expression in art. The Swiss painter Ferdinand Hodler made a sort of manifesto of rhythmically organised collective movement and gesture that left a notable impact on contemporary culture (Auszug der Jenenser Studenten in den Freiheitskrieg 1813, 1908-9; Unanimity. The people of Hannover under the leadership of Dietrich Arnsborg declare for the Reformation, 1913). He found sources of inspiration for his concept of Parallelism not only in Nature, but also in social life, above all in the manifestations of collective emotions that imparted a similar rhythm of movement to the people. The military marching step and the gymnastics step of the Jena students are equally archaic and modern. They reference numerous examples of representation in Assyrian, Egyptian or Roman art. At the same time, this marching step is a specific modernist combination: on the one side, of rational construction and, on the other, of the irrational elements of rhythm captivating and engulfing the individual.

Before the war Russian art had produced no such vivid formulas of the rhythmically organised masses. More often than not militarised rhythms, the rhythms of discipline evoked rejection. Another version of collective rhythm represented in European art, for instance, by G. Klimt's Beethoven Frieze (1902) was closer to home. Conventionally, it can be called the somnambulist rhythm of the masses. For example, in his early works Malevich came up with a version of Klimt-like somnambulist crowds in ecstatic contemplation (Study of fresco painting. Self-portrait 1907; Study of fresco painting 1907).

A new image of the crowd appeared in Russian art in representations of the war and then the revolution. Some works depicting the war have emphasised rhythmicity, repetitive mechanics and accentuated linear rhythm. Thus, in some scenes of O. Rozanova's War cycle of linocuts (1916) there appears linear rhythm based on the principle of parallelism, together with emphasised rhythmicity, which serves to show a multitude of people. The war experience proved for Russian culture a prologue of sorts to a new experience of the organised and militarised crowd, attuned to the rhythm and wallowing in the pleasure of automatism.

An upsurge of interest in the iconography of rhythmically moving crowds occurred during the war and right after the revolution. Conventionally speaking, the rhythmic step of the masses emerged as the most common archetype of that period, a visual formula of a new society. Those marching and rhythmically organised masses appeared in the works of different artists. These include Sketches for Tverskaia Street Decoration by N. Lakov and G. Grinberg (1918), Study of a Panel by V. Baranov-Rossine (1918), Studies of a Panel for the Decoration of Smolny in Petrograd by Y. Guminer (1918), A Study of a Panel for the Festive Decoration of Moscow by L. Feinberg (1918), The Red Army (La Marseillaise) by K. Chebotarev (1917) and Uprising by K. Redko (1924). In the period of Enlightenment the motif of a walk and walking step itself had special importance as a gesture of sorts of the self-asserting new social class and its new aesthetics [19], the sauntering pace of a flaneur in the city streets or arcades became such a symbol in the second half of the 19th century, the new symbol now was the militarised gymnastic step of the rhythmically moving masses. Strolling outdoors or sauntering along the city streets were, beyond doubt, practices that cultivated the individual. The new step of the rhythmically organised masses levelled out the individual spirit and established the collective one. Such a step called for special surroundings in the form of space organised in a special way. It hardly agrees with natural landscapes and finds the vacant spaces of stadiums and squares, that is, those cleared of any signs of everyday life, most suitable for itself in the urban environment. Small wonder that Adolphe Appia produced special scenic designs for Dalcroze's performances: a vacant space with rhythmically marching actors surrounded by regular geometrical shapes.

The rhythmic step motif is associated in pictorial art not only with Hodler's (military or sports) iconography, but also with archaic-like primitivist tendencies. It also brings to mind lubok prints or wartime mass media products that frequently featured oversimplified signal images of a multitude of people. Mention can be made of Malevich's wartime postcards ("Out of Lvov in the morning...", Segodniashnii lubok publishing house, 1914) or numerous wartime prints and magazine illustrations.

The "rhythmic or stagnating mass" (E. Canetti) served to effect the "total mobilisation" of society and to introduce the principles of military organisation into the "diffused crowd". Those images also evoked subconscious association with the ideal "paradise" socium. The images of rhythmically organised crowds in the art of the early revolutionary period can be interpreted as a sort of parodies of angelical hierarchies. I use the word "parody" the way Tynianov interpreted it as a special mechanism of producing something new. The rhythmically organised and regulated "crowds" of angels or saints in heaven were an important iconographical prototype of the ideal collective bodies. At the level of subconscious associations and cultural archetypes the rhythmically organised masses referenced images of humankind purified and taken to heaven after the Last Judgement. It can be surmised that such "heavenly" visions of the masses indirectly reflected wartime expectations of "the new sky and new earth". It is noteworthy that similar associations arose in Malevich's writings of the late 1910s in connection with the ideas of the new "we culture". In his programmatic text "About I and the Collective" Malevich writes: "to go forth to perfection one has to destroy oneself as the saintly fanatics did before the deity, so the modern saint ought to destroy himself before the 'collective' ...the modernity is now aspiring to attain the kingdom of heaven 
on earth through unity brotherhood and the unification of nations"[20].

However, it is important to point out a significant difference: the angels and the "heavenly host" reside rather than move or march: they lack dynamism. Conversely, the new masses walk and march in a bid to overcome and conquer space. Conventionally speaking, the rhythmically organised crowds are a simulacrum of the "heavenly" or its deformed afterimage, its disappearing trace in the space of new culture. A new mythical person is born in the rhythmically organised crowds instead of the "heavenly host" of saints or angels. The rhythmically organised multitudes of people are free from negative associations with criminal or spontaneous crowds. They are above all the images of new power and energy devoid of anything individual. In 1919 Malevich described the organisms of the new world as follows: "its organisms are soul-less and mindless, will-less, but powerful and strong. They are free from God and the church and any religion, they live and breathe, but their chests do not move nor hearts beat, and the brain transplanted to their bodies moves them and itself with renewed power; for the time being I consider dynamism to be that force which has replaced the spirit'[21]

Ornamentalising the masses is one of the principal ways of organising them. Ornament is the graphic embodiment of rhythm. Already in the 19th century ornament became a key element of aesthetical theories. Formulas of the national spirit and collective identity were seen in the specifics of folk ornament. In the early 1920s Florensky wrote: "Ornament is more philosophical than the other branches of pictorial art, because it does not depict individual things or their particular correlations, but makes certain world formulas of being visual"[22] Like rhythm, ornament is linked to pleasure. According to John Ruskin, "[Gothic] ornament was an expression of the artisan's joy" [23]. In the past people saw formulas of divine creation, formulas of spontaneous creativity of the national spirit in ornaments, whereas in the early 20 th century they looked for ways to produce rationally new ornamental formulas of collective unity.

Suprematist ornament can be regarded as one of the most consistent versions of new ornamentation linked with the aesthetics of the collective. Suprematism's speedy and natural shift from metaphysics to ornament and the ornamentation of life was predetermined not only by external factors, but by the very philosophy of Suprematist form and orientation to building life and collectivism. Suprematist ornament fell in tune with the mass ornaments practiced in early 20th-century culture. The mass ornament pictured in the scenes of 19th-century parades was based on a system of local sharply outlined geometrical shapes that subordinated the masses to their logic and formalised them. That ornament rather localised, enclosed and formalised the elements of the mass. Integral geometrical shapes rather than the rhythms of individual bodies predominated in it. The mass ornament emerging in the practices of constructing collective bodies of early 20th-century culture was of an altogether different nature. Like the new crowds, new ornament was diffused and based on uniform statistical units - the individuals with their endless inversions and multiplications. New ornament represented not the shapes as such, but rather the very process of their multiplication, proliferation and circulation of shapes. The structure of such ornaments presupposes no borders, neither the starting point nor the end of ornament. New ornament no longer enclosed or limited. On the contrary, it manifested infinity and demonstrated the unlimited energy of the masses (shapes). Represented on the stage, in the picture, square or stadium, the ornament could unfold indefinitely in space, encompassing new territories and involving ever new multitudes of people (shapes) with no detriment to its structure. It could extend indefinitely, knowing no entropy or exhaustion of rhythmical forces. It was devoid of any effort to master space plastically; quite the opposite, new ornament passively got suspended in vacuum and followed infinite space.

In his book Sublime Historical Experience F.R. Ankersmit describes rococo ornament as a plastic formula of the period of the Enlightenment. "S curves presuppose victory over space and infinity. (...) ...rococo ornament reflects the mood of the Enlightenment's discovery of the physical world and ... it celebrates the victory of the modern man over physical reality that was so much the Enlightenment's pride. If Newtonian science inspired the Enlightenment's confidence to conquer space and time, rococo ornament is the artistic expression of this confidence"'[24]. New ornament is likewise a plastic formula of its epoch. It is based on the experience of infinity that escapes the individual's rationality and on rhythmic pulsation that replaces the linear movement of time. New ornament is a formula of the dissolution of the individual and its being absorbed by impersonal forces. It rests on the manifestation of the defeat of earlier rationality rather than on the willfully rational organisation of space. Cloaked in outwardly rational shapes, new ornament camouflages that defeat just as military marching and formation conceal the somnambulic nature of the crowd and new socium.

\section{CONCLUSION}

A walking lunatic is the image of a new force that is building a new world and combines geometry and regular movement with the hypnotic, somnambulic state of a man of the crowd. For El Lissitzky such an image of a lunatic moving in keeping with regular geometry becomes a metaphor of the triumphant march of the new world. In his programmatic essay Preodolenie iskusstva (Overcoming Art, 1921) Lissitzky writes: "new world will be constructed [and] it will be built with a force that overcomes both art, science, and technology. It will be constructed with a direct and precise force, like the path of a lunatic before whom everything retreats in shame" [25].

\section{REFERENCES}

[1] S. Kracauer. The Mass Ornament. Weimar Essays. Cambridge, Massachusetts: Harvard University Press, 1995, p. 79.

[2] S. Bulgakov, Voina i russkoye samosoznanie (The War and Russian Self-consciousness). Moscow, 1915, p. 57.

[3] Cit.: C. Borch. The Politics of Crowds. Cambridge University Press, 2012, p.76.

[4] Ibid. 
[5] P. Krasnov, Dusha armii. Russkaia voennaia emigratsia o moral'nopsikhologicheskikh osnovakh rossiiskoi vooruzhennoi sily (The Soul of the Army. Russian Military Emigrants on the Ethical and Psychological Foundations of the Russian Armed Forces). Moscow, 1999, p. 83.

[6] A. Rezanov. Armia i tolpa. Opyt voennoi psikhologii (The Army and the Crowd. Essay on Military Psychology), Warsaw, 1910, p. 24.

[7] A. Rezanov. Ibid., p. 62.

[8] P. Krasnov. Op. cit., p. 129.

[9] A. Rezanov, Op. cit., p. 37.

[10] Ibid., p. 63.

[11] Cit. S. Moscovici. The Age of the Crowd: A Historical Treatise on Mass Psychology. Cambridge University Press, 1985, p. 161.

[12] Zh.Vigarello. R.Kholt. Rabota nad telom. Gimnasty i sportsmeny v 19 veke. - Istoriya tela. Tom 2. M.. 2014. s. 272. 301.

[13] V. Bekhterev. Iubileinye dni v Prage $i$ vospitatel'noie znachenie sokolstva (Celebration Days in Prague and Educational Value of the Sokol Movement). Petrograd, 1915, pp. 8-9.

[14] E.Zhak-Dalkroz. Rim. Ego vospitatelnoye znacheniye dlya zhizni i dlya iskusstva. PG.. b/g. s.101

[15] É. Jaques-Dalcroze. Rhythm, Music, and Education, 1921, pp. 223, 227.

[16] E. Meerson. Sistema Zhak-Dalkroza (The System of Jaques-Dalcroze) // Zapiski Peredvizhnogo teatra, Issue 12, Oct. 1918, p. 12.

[17] K.Byukher Rabota i ritm. Rabochiye pesni. ikh proiskhozhdeniye. esteticheskoye i ekonomicheskoye znacheniye. SPB. 1899. P.79

[18] Cit. S. Moscovici, Op. cit, p. 26.

[19] For details see A.Hewitt. Social Choreography: Ideology as Performance in Dance and Everyday Movement. Duke University Press, 2005.

[20] K. Malevich. "O Ia i kollektive" (About I and the Collective) // Cit. text published by T. Goriacheva in Sovershennyi chelovek. Teologia $i$ filosofia obraza (Modern Man. Image Theology and Philosophy). Moscow, 1997, pp. 395-6.

[21] K. Malevich. Letter to Gershenzon of 21 Dec. 1919. In Malevich o sebe. Sovremenniki o Maleviche. Letters. Documents. Memoirs. Criticism. In 2 vols. Vol. 1, Moscow, 2004, p. 118.

[22] P. Florensky. Istoria i filosofia iskusstva. Stat'i $i$ issledovania po istorii $i$ filosofii iskusstva $i$ arkheologii (History and Philosophy of Art. Articles on and Studies of the History and Philosophy of Art and Archaeology), Moscow, 2000. http://publ.lib.ru/ARCHIVES/F/FLORENSKIY_Pavel_Aleksandrovi ch/_Florenskiy_P.A..html

[23] Dzhon Reskin. Lektsii ob iskusstve. M.. 2006.

[24] F.R. Ankersmit. Sublime Historical Experience, Standord University Press, 2005, p. 311.

[25] El Lissitzky. "Preodolenie iskusstva" (Overcoming Art). Experiment. A Journal of Russian Culture. Vol. 5, 1999, p. 149. Cit. Nancy Lynn Perloff, Brian Reed, Situating El Lissitzky: Vitebsk, Berlin, Moscow, p. 143. 